\title{
Efficacy and safety of tiotropium and olodaterol in COPD: a systematic review and meta-analysis
}

\author{
Marc Miravitlles $^{1 *+} \mathbb{D}$, Gerard Urrutia ${ }^{2 \dagger}$, Alexander G. Mathioudakis $^{3}$ and Julio Ancochea ${ }^{4}$
}

\begin{abstract}
Background: Long-acting bronchodilators are the cornerstone of pharmacologic treatment of COPD. The new combination of long-acting muscarinic antagonist (LAMA) tiotropium (TIO) and long acting beta-agonists (LABA) olodaterol (OLO) has been introduced as fist line therapy for COPD. This article analyses the evidence of efficacy and safety of the TIO/OLO combination.
\end{abstract}

Methods: A systematic review and metaanalysis of randomized controlled trials (RCT) with a period of treatment of at least 6 weeks, in patients with COPD confirmed by spirometry, comparing combined treatment with TIO/OLO (approved doses only), with any of the mono-components or any other active comparator administered as an inhalator.

Results: A total of 10 Randomized controlled trials $(R C T)$ were identified $(N=10,918)$. TIO/OLO significantly improved trough FEV from baseline to week 12 versus TIO, OLO and LABA/ICS (0.06 L, $0.09 \mathrm{~L}$ and between 0.04 and $0.05 \mathrm{~L}$, respectively). TIO/OLO improved transitional dyspnea index (TDI) and St. George's Respiratory Questionnaire (SGRQ) compared with mono-components, with patients more likely to achieve clinically important improvements in TDI (risk ratio [RR]: 1.17, 95\% confidence interval [Cl]: [1.07, 1.28] versus TIO and RR: 1.14, 95\%Cl: [1. $01,1.28]$ versus OLO) and in SGRQ (RR: 1.21,95\%Cl: [1.12, 1.30] versus TIO and RR: 1.28, 95\%Cl: $[1.18,1.40]$ versus OLO). Patients treated with TIO/OLO showed a significant reduction in the use of rescue medication and no significant differences in frequency of general and serious adverse events were observed between TIO/OLO and mono-components.

Conclusions: Treatment with TIO/OLO provided significant improvements in lung function versus monocomponents and LABA/ICS with more patients achieving significant improvements in dyspnea and health status. No differences in adverse events were observed compared with other active treatments.

Clinical trial registration: PROSPERO register of systematic reviews (CRD42016040162).

Keywords: Systematic review, Metanalysis, COPD, Tiotropium, Olodaterol, Tiotropium/olodaterol fixed dose combination

\footnotetext{
*Correspondence: mmiravitlles@vhebron.net

${ }^{\dagger}$ Equal contributors

'Pneumology Department, Hospital Universitari Vall d'Hebron., P. Vall

d'Hebron 119-129, ES-08035 Barcelona, Spain

Full list of author information is available at the end of the article
}

\section{Ciömed Central}

(c) The Author(s). 2017 Open Access This article is distributed under the terms of the Creative Commons Attribution 4.0 International License (http://creativecommons.org/licenses/by/4.0/), which permits unrestricted use, distribution, and reproduction in any medium, provided you give appropriate credit to the original author(s) and the source, provide a link to the Creative Commons license, and indicate if changes were made. The Creative Commons Public Domain Dedication waiver (http://creativecommons.org/publicdomain/zero/1.0/) applies to the data made available in this article, unless otherwise stated. 


\section{Background}

Long-acting bronchodilators represent the backbone of available treatments for chronic obstructive pulmonary disease (COPD) [1]. Both long-acting muscarinic antagonists (LAMA) and long acting beta-agonists (LABA) confer significant benefits to patients with COPD, which include but are not limited to improvement in lung function, symptoms, health status and reduction in the exacerbations rate [2-4]. Fixed-dose combinations (FDC) of a LAMA with a LABA were recently introduced and there are increasing number of studies supporting their efficacy and safety [5-7]. LAMA/LABA combination was included in the most recent Global Initiative for Chronic Obstructive Lung Disease (GOLD) strategy as a first line choice therapy for group D (high risk and symptoms) and recommended second option in $\mathrm{B}$ (low risk, high symptoms) and $\mathrm{C}$ (high risk, low symptoms) groups [1], and the Spanish COPD guidelines recommend the use of LABA/LAMA combinations as first line therapy in patients highly symptomatic and/or at risk for exacerbations [8].

The efficacy and safety of both tiotropium (TIO), the first LAMA introduced in clinical practice, and the LABA olodaterol (OLO) have been extensively evaluated in trials and also in clinical practice $[3,4,9]$. TIO/OLO FDC $(5 / 5 \mu \mathrm{g})$, recently approved for the treatment of COPD, has been thoroughly assessed for its efficacy and safety in COPD $[10,11]$.

Since the combination TIO/OLO is now approved for first line therapy in COPD it is necessary to evaluate the evidence accumulated about its efficacy and safety in these patients. Therefore, the aim of this systematic review was to assess the comparative efficacy, in terms of trough forced expiratory volume in $1 \mathrm{~s}$ (trough $\mathrm{FEV}_{1}$ ), quality of life with St. George's Respiratory Questionnaire (SGRQ), dyspnea (Mahler Transition Dyspnoea Index focal score), exercise capacity, use of rescue medication and safety outcomes of TIO/OLO in combination, either administered in separate or same inhaler, versus the mono-components or any other active comparator (inhaled), in adult patients with COPD.

\section{Methods}

This systematic review methodology is based on a protocol which was registered in PROSPERO register of systematic reviews (CRD42016040162). The report follows the Preferred Reporting Items for Systematic Reviews and Meta-analyses Statement (PRISMA) guidance [12].

\section{Study selection criteria}

Eligible studies were randomized controlled trials (RCT) with a period of treatment and follow up of at least 6 weeks, in patients with a history of COPD confirmed by spirometry, comparing combined treatment with
TIO/OLO, either administered in a single or separate inhalers, with any of the mono-components or any other active comparator administered as an inhalator. The RCT should report on at least one of the following outcome measures: trough forced expiratory volume in $1 \mathrm{~s}$ (trough $\mathrm{FEV}_{1}$ ), quality of life assessed with the St. George's Respiratory Questionnaire (SGRQ), symptoms (dyspnea) assessed with the Mahler Transition Dyspnoea Index focal score, exercise capacity, use of rescue medication or safety outcomes, such as all and serious adverse events. The primary objective of this meta-analysis was efficacy.

\section{Search methods}

We searched MEDLINE and EMBASE through OVID, as well as Cochrane CENTRAL (from inception up to May 2016), using appropriate controlled vocabulary and free search terms (detailed search strategy containing the keywords is provided in Additional file 1). We searched trial registries via the World Health Organization International Clinical Trials Platform Search Portal (ICTRP) for ongoing or completed studies (http://apps.who.int/trialsearch/) (accessed in December 2016).

Finally, we checked the reference lists of all trials that were identified by the above mentioned searches.

\section{Study selection and data extraction}

All titles screening as well as full text eligibility assessment were performed by one of the authors (AM). From this list, the references that clearly did not meet the eligibility criteria were excluded. Another reviewer reassessed and validated study selection (GU). Minor disagreements were resolved through discussion. Data from each study was extracted by one author (AM) and validated by a second author (GU) in detailed tabulated data extraction forms, with a cross check against the original papers. Variables to be extracted from each reference were: i) study identification, ii) methods details, and iii) outcome data (related to those data previously specified in the study selection criteria).When required, additional data were requested to the investigators or the sponsor.

\section{Risk of bias and heterogeneity assessment}

Risk of bias was assessed using the criteria outlined in the Cochrane Handbook for Systematic Reviews of Interventions [13] by one author (AM) and was validated by an additional author (GU). Disagreements were resolved by discussion.

We used the $\mathrm{I}^{2}$ statistic to measure heterogeneity among the trials in each analysis [13]. When substantial heterogeneity was identified $\left(\mathrm{I}^{2} \geq 75 \%\right.$.), we reported this and explored possible causes by performing prespecified subgroup analyses. 


\section{Data analysis}

Meta-analyses were performed only when this was meaningful, while the rest of our findings were presented narratively. Dichotomous data were analyzed by calculating risk ratios (RR) and the corresponding 95\% confidence intervals (CI), continuous data by calculating mean differences (MD) or standardized mean differences (SMD) and $95 \% \mathrm{CI}$ and time-to-event data by the inverse variance method.

For data synthesis we used the fixed or random effect models in the absence of important heterogeneity or in the presence of moderate heterogeneity, respectively. In case of substantial heterogeneity, which cannot be resolved by performing the subgroup analyses, we did not perform meta-analysis. Review Manager 5.3 software was used for this meta-analysis.

\section{Results}

Search strategies yielded 201 unique references, of which five met the eligibility criteria. In addition, reports of two more unpublished studies were identified in ICTRP (Fig. 1: Flow diagram of study selection). We identified a total of 10 RCT involving 10,918 participants that were eligible for the review: ANHELTO 1 \& 2 (published in one article) [14], ENERGITO [15], MORACTO 1 \& 2 $[16,17]$, OTEMTO $1 \& 2[18,19]$, TONADO $1 \& 2[20$, 21] and VIVACITO [22]. We identified one additional RCT that has been completed published only as a protocol [23, 24] (PHYSACTO), and one more trial that is still ongoing (DYNAGITO) [25].

Another two RCT assessing the combined treatment with TIO/OLO were excluded due to the short follow up period (4 weeks) [26], or the lack of a comparison with any of the mono-components or an active control (TORRACTO) [27].

\section{Description of the studies}

Details on the characteristics of the included studies are provided in Table 1 (Characteristics of the included studies: summary) and Additional file 2: Table S1.

Six studies had a parallel group design, with a sample size ranging from 607 and 1577 participants, whereas the other four had a crossover design that included between 219 and 295 participants (mean 1091; median 809). All studies except ANHELTO 1 \& 2 (which were conducted exclusively in the US) were multinational with a wide range of participating countries. Treatment duration was 6 weeks (4 studies), 12 weeks (4 studies) and 24 weeks ( 2 studies), with an additional extension up to 54 weeks in the later ones.

All trials (except ANHELTO 1 \& 2) assessed oncedaily TIO/OLO FDC, which was administered with the use of a single inhaler (Respimat $\left.{ }^{\odot}\right)$. By contrast, in ANHELTO 1\&2, the combination treatment TIO + OLO was administered using two different inhalers (HandiHaler ${ }^{\oplus}$ and Respimat $\left.{ }^{\oplus}\right)$. Regarding the dosing of TIO in the combined treatment, ANHELTO 1 \& 2 used TIO $18 \mu \mathrm{g}$, whereas all the rest assessed two different FDC using high and low doses of TIO (5 $\mu \mathrm{g}$ and $2.5 \mu \mathrm{g})$. OLO was always administered at the same dose of $5 \mu \mathrm{g}$. For the purposes of this review, only data from TIO/OLO FDC arms where high dose of $\mathrm{TIO}(5 \mu \mathrm{g})$ were used have been included, as the low dose $(2.5 \mu \mathrm{g})$ is not marketed.

Nine studies had a control group with TIO (5 or $18 \mu \mathrm{g})$, and five a control group with OLO $(5 \mu \mathrm{g})$. Only one study compared the combined therapy with $\mathrm{TIO} /$ OLO versus the combined therapy with salmeterol plus fluticasone at two different dose combination $(50 / 500 \mu \mathrm{g}$ or $50 / 250 \mu \mathrm{g})$ [15].

Overall, the inclusion criteria and populations' characteristics of the studies were very homogeneous. Participants were aged $\geq 40$ years, current or ex-smokers with a smoking history of more than 10 pack-years, mostly with moderate to severe COPD; only TONADO 1 \& 2 included participants with very severe disease $\left(\mathrm{FEV}_{1}<30 \%\right.$ predicted, $10.8 \%$ of the participants). All studies required participants to be able to inhale medication in a competent manner from the Respimat ${ }^{\circledR}$ or HandiHaler ${ }^{\bullet}$ inhalers as well as to perform technically acceptable pulmonary function tests, and maintain records (paper diary) as required.

\section{Risk of bias of the included studies}

Risk of bias was deemed low for all domains evaluated in all included trials (details in Additional file 3: Figure S1 and Additional file 4: Figure S2). Risk of bias was assessed according the criteria outlined in the Cochrane Handbook. Where no sufficient details were provided in the article (i.e. allocation concealment), these were requested to the sponsor who provided further details.

\section{Efficacy of the intervention}

Trough $\mathrm{FEV}_{1}$ was reported in eight of the RCT [14, 15, 18-22]. Overall, the combined therapy proved to be superior to the mono-components in all studies (Fig. 2: Trough $\mathrm{FEV}_{1}$ ). TIO/OLO was associated with significantly higher trough $\mathrm{FEV}_{1}$ when compared with TIO (MD 0.06 [0.04 to 0.07], $\mathrm{I}^{2}=33 \%$ ) (5 RCT with 3101 patients) or OLO (MD 0.09 [0.07-0.10], $\mathrm{I}^{2}=0 \%$ ) (3 RCT with 2313 patients). TIO/OLO showed a statistically significant greater improvement in trough $\mathrm{FEV}_{1}$ after 6 weeks of treatment compared to both doses of salmeterol plus fluticasone (with an improvement ranging between 42 and $58 \mathrm{~mL}$ ). When treatment was administered in separate inhalers, TIO + OLO $(18 / 5 \mu \mathrm{g})$ resulted in significant improvements over TIO $(18 \mu \mathrm{g})$ in trough $\mathrm{FEV}_{1}$ (treatment differences: $62 \mathrm{~mL}[P<0.001]$ in ANHELTO 1; $40 \mathrm{~mL}[P$ $=0.0029]$ in ANHELTO 2) [14]. 


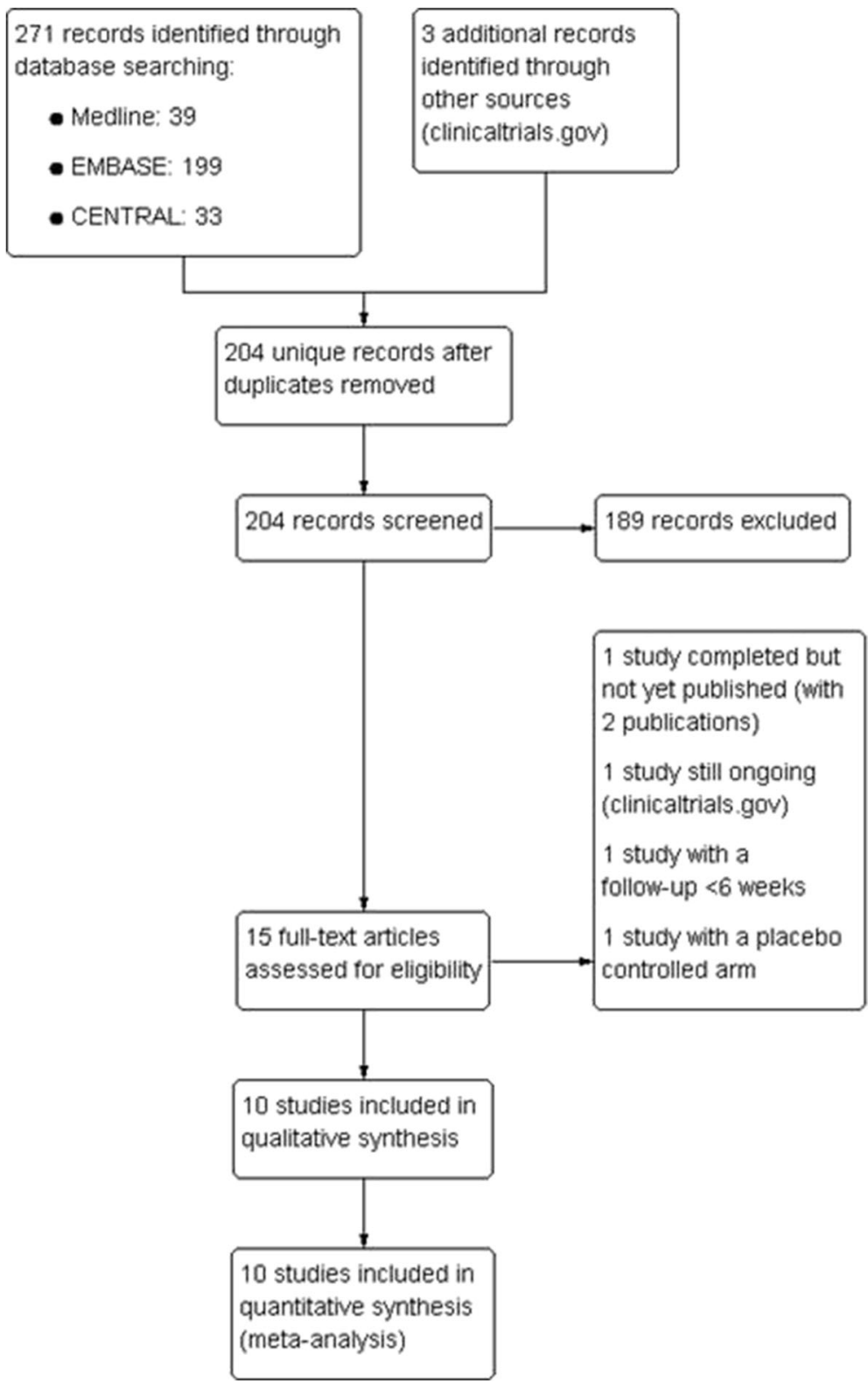

Fig. 1 Flow diagram of study selection

TIO/OLO was associated with an improved quality of life compared to TIO (MD -1.56 [-2.41 to -0.71$]$, $\left.\mathrm{I}^{2}=0 \%\right)$ in 4 RCT with 2697 participants $[14,18,19]$ or OLO $(-1.69$ [ -2.77 to -0.61$])$ in 2 RCT with 1933 participants [20, 21] (Fig. 3: Quality of life SGRQ: change from baseline). More participants receiving TIO/OLO had a clinically meaningful difference in SGRQ compared to TIO $[14,18,19]$ (RR 1.21 [1.12 to 1.30$\left.], \mathrm{I}^{2}=0 \%\right)$ or OLO $[20,21]$ (RR 1.28 [1.18 to 1.40]) (Fig. 4: Quality of life SGRQ: responders).

Similar results were found for TIO + OLO $(18 / 5 \mu \mathrm{g}) \mathrm{vs}$ TIO, both in the SGRQ total score change [14] (MD:
$-1.90[-2.80$ to -1.00$])$ and SGRQ responders rate (RR 1.16 [1.06 to 1.27]) (Figs. 3 and 4).

Four studies measured the Mahler Transition Dyspnea Index (TDI) [18-21]. TIO/OLO led to improved TDI compared to TIO (MD $0.43[0.22$ to 0.65$], \mathrm{I}^{2}=1 \%$ ) and OLO (RR 0.42 [0.16 to 0.68]) (Fig. 5: Symptoms TDI: change from baseline). More participants receiving TIO/ OLO had a clinically meaningful difference in TDI score ( $\geq 1.0$ unit) compared to TIO (RR 1.17 [1.07 to 1.28], I2 $=75 \%$ ) or OLO (RR 1.14 [1.01 to 1.28]) (Fig. 6: Symptoms TDI: responders).

Rescue medication usage was lower with $\mathrm{TIO}+\mathrm{OLO}$ $(18 / 5 \mu \mathrm{g})$ than with TIO [14, 18-21]. On average, TIO + 
Table 1 Characteristics of the included studies: summary

\begin{tabular}{|c|c|c|c|c|c|}
\hline Study, Year & Intervention (Participants) & Design, Follow up & Multicenter/ Double blind & Baseline characteristics & Risk of Bias \\
\hline $\begin{array}{l}\text { ANHELTO } 1 \& 2 \\
2014\end{array}$ & 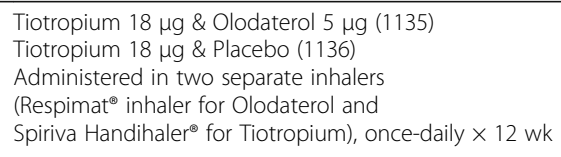 & $\begin{array}{l}\text { Parallel RCT, } \\
15 \text { weeks }\end{array}$ & $\checkmark / \checkmark$ & $\begin{array}{l}\text { Mean(SD) age }-51.7(9) \\
\text { Male - } 51.7 \% \\
\text { Ex-smokers - } 51 \% \\
\text { GOLD 2-58.9\%, } \\
\text { GOLD 3-41.1\% }\end{array}$ & Low \\
\hline $\begin{array}{l}\text { ENERGITO } \\
2016\end{array}$ & $\begin{array}{l}\text { Tiotropium } 2.5 \mu \mathrm{g} \& \text { Olodaterol } 5 \mu \mathrm{g} \\
\text { Tiotropium } 5 \mu \mathrm{g} \& \text { Olodaterol } 5 \mu \mathrm{g} \\
\text { [FDC via Respimat, once-daily } \times 6 \mathrm{wk} \text { ] } \\
\text { Salmeterol \& Fluticasone } 50 / 250 \mu \mathrm{g} \\
\text { Salmeterol \& Fluticasone } 50 / 500 \mu \mathrm{g} \\
(N=229 \times 4)\end{array}$ & $\begin{array}{l}\text { Crossover RCT, Participants } \\
\text { completed } 4 / 4 \text { arms } \\
>6 \text { weeks }\end{array}$ & $\sqrt{ } / \mathrm{S}$ & $\begin{array}{l}\text { Mean(SD) age - 63.6(7.6) } \\
\text { Male }-64.6 \% \\
\text { Ex-smokers - } 55.5 \% \\
\text { GOLD 2-72.1\%, } \\
\text { GOLD } 3-27.9 \%\end{array}$ & Low \\
\hline $\begin{array}{l}\text { MORACTO } 1 \& 2 \\
2015\end{array}$ & $\begin{array}{l}\text { Tiotropium } 2.5 \mu \mathrm{g} \& \text { Olodaterol } 5 \mu \mathrm{g} \\
\text { Tiotropium } 5 \mu \mathrm{g} \& \text { Olodaterol } 5 \mu \mathrm{g} \\
\left.\text { [FDC via Respimat }{ }^{\oplus} \text {, once-daily } \times 6 \mathrm{wk}\right] \\
\text { Tiotropium } 5 \mu \mathrm{g} \\
\text { Olodaterol } 5 \mu \mathrm{g} \\
\text { Placebo } \\
(N=586 \times 4)\end{array}$ & $\begin{array}{l}\text { Crossover RCT, Participants } \\
\text { completed } 4 / 5 \text { arms, } \\
\mathbf{6} \text { weeks }\end{array}$ & $\checkmark / S$ & $\begin{array}{l}\text { Mean(SD) age }-61.7(7.7) \\
\text { Male }-71.2 \% \\
\text { Ex-smokers - 60.9\% } \\
\text { GOLD 2-71\%, } \\
\text { GOLD 3-28\% }\end{array}$ & Low \\
\hline $\begin{array}{l}\text { OTEMTO } 1 \& 2 \\
2015\end{array}$ & $\begin{array}{l}\text { Tiotropium } 2.5 \mu \mathrm{g} \& \text { Olodaterol } 5 \mu \mathrm{g}(404) \\
\text { Tiotropium } 5 \mu \mathrm{g} \& \text { Olodaterol } 5 \mu \mathrm{g}(406) \\
\text { [FDC via Respimat, } \text {, once-daily } \times 12 \mathrm{wk}] \\
\text { Tiotropium } 5 \mu \mathrm{g}(407) \\
\text { Placebo (406) }\end{array}$ & $\begin{array}{l}\text { Parallel RCT, } \\
15 \text { weeks }\end{array}$ & $\checkmark / \checkmark$ & $\begin{array}{l}\text { Mean(SD) age }-64.7(8.4) \\
\text { Male }-60.9 \% \\
\text { Ex-smokers - } 52.9 \% \\
\text { GOLD 2-64.4\%, } \\
\text { GOLD } 3-35.6 \%\end{array}$ & Low \\
\hline $\begin{array}{l}\text { TONADO } 1 \& 2 \\
2015\end{array}$ & $\begin{array}{l}\text { Tiotropium } 2.5 \mu \mathrm{g} \& \text { Olodaterol } 5 \mu \mathrm{g}(1030) \\
\text { Tiotropium } 5 \mu \mathrm{g} \& \text { Olodaterol } 5 \mu \mathrm{g}(1029) \\
\left.\text { [FDC via Respimat }{ }^{\oplus} \text {, once-daily } \times 52 \mathrm{wk}\right] \\
\text { Tiotropium } 2.5 \mu \mathrm{g}(1032) \\
\text { Tiotropium } 5 \mu \mathrm{g}(1033) \\
\text { Olodaterol } 5 \mu \mathrm{g}(1038)\end{array}$ & $\begin{array}{l}\text { Parallel } \mathrm{RCT} \text {, } \\
\mathbf{5 2} \text { weeks }\end{array}$ & $\checkmark / \checkmark$ & $\begin{array}{l}\text { Mean(SD) age - 646(8.3) } \\
\text { Male - } 73.3 \% \\
\text { Ex-smokers - 63.\% } \\
\text { GOLD 2-50.1\%, } \\
\text { GOLD 3,4-49.9\% }\end{array}$ & Low \\
\hline $\begin{array}{l}\text { VIVACITO } \\
2015\end{array}$ & $\begin{array}{l}\text { Tiotropium } 2.5 \mu \mathrm{g} \& \text { Olodaterol } 5 \mu \mathrm{g} \\
\text { Tiotropium } 5 \mu \mathrm{g} \& \text { Olodaterol } 5 \mu \mathrm{g} \\
\text { [FDC via Respimat }{ }^{\oplus} \text {, once-daily } \times 6 \mathrm{wk} \text { ] } \\
\text { Tiotropium } 2.5 \mu \mathrm{g} \\
\text { Tiotropium } 5 \mu \mathrm{g} \\
\text { Olodaterol } 5 \mu \mathrm{g} \\
\text { Placebo } \\
(\mathrm{N}=259 \times 6)\end{array}$ & $\begin{array}{l}\text { Crossover RCT, Participants } \\
\text { completed } 4 / 6 \text { arms, } \\
\mathbf{6} \text { weeks }\end{array}$ & $\checkmark / \sqrt{ }$ & $\begin{array}{l}\text { Mean(SD) age - } 61.1(7.7) \\
\text { Male - } 58.9 \% \\
\text { Ex-smokers - } 37.4 \% \\
\text { GOLD 2-63.5\%, } \\
\text { GOLD 3,4-36.5\% }\end{array}$ & Low \\
\hline
\end{tabular}

OLO reduced the number of days using rescue medication by 8.5 days $(95 \%$ CI 4.2, 12.8) in ANHELTO 1 and by 7.2 days (95\% CI 3 to 11.49 ) in ANHELTO 2. In OTEMTO $1 \& 2$, the use of rescue medication over $24 \mathrm{~h}$ was lower in patients receiving TIO/OLO compared to TIO after 12 weeks $(P<0.05)$ (post-hoc analysis). In TONADO $1 \& 2$, TIO/OLO provided reductions in adjusted weekly mean daily (24-h) rescue medication use compared to the mono-components throughout the 52week treatment period.

MORACTO 1 \& 2 trials showed a trend over increased endurance time for TIO/OLO compared to TIO (MD 8.06 [-13.76 to 29.87], $\mathrm{I}^{2}=99 \%$ ) or OLO (MD $23.67[-21.34$ to 68.69$], \mathrm{I}^{2}=100 \%$ ); however, these results are limited by the significant heterogeneity between the two included trials.

Regarding safety, no differences were observed in the frequency of general and serious adverse events between $\mathrm{TIO} / \mathrm{OLO}$ and the mono-components. All adverse events were reported in ANHELTO 1 \& 2, OTEMTO 1 \& 2, TONADO 1 \& 2, VIVACITO and ENERGITO trials. No significant differences between groups were observed when comparing TIO/OLO versus mono- components (RR 0.99 [0.96 to 1.02$], \mathrm{I} 2=0 \%$ ) or versus salmeterol fluticasone (RR 1.02 [0.85 to 1.23]) (Fig. 7: All adverse events). Serious adverse events were assessed in ANHELTO 1 \& 2, OTEMTO 1 \& 2, TONADO 1 \& 2, VIVACITO and ENERGITO trials. A similar between group distribution was observed between participants receiving TIO/OLO versus mono-components or placebo (RR 0.99 [0.88 to 1.11 ], I2 = 49\%). Also, ENERGITO trial concluded similar number of serious adverse events were observed between participants receiving TIO/OLO versus fluticasone/salmeterol (RR 0.80 [0.39 to 1.65]).

\section{Discussion}

The results of our analysis showed that TIO/OLO is an effective and safe treatment for patients with COPD of a very wide range of severity. The data obtained in the RCT have demonstrated significant improvements in through FEV1, SGRQ, dyspnea scores and a reduction in the use of rescue medication compared with the monocomponents, and a significant improvement in through FEV1 in one study compared to LABA/ICS combination. No safety issues were identified in the comparative analysis with the mono-components. 


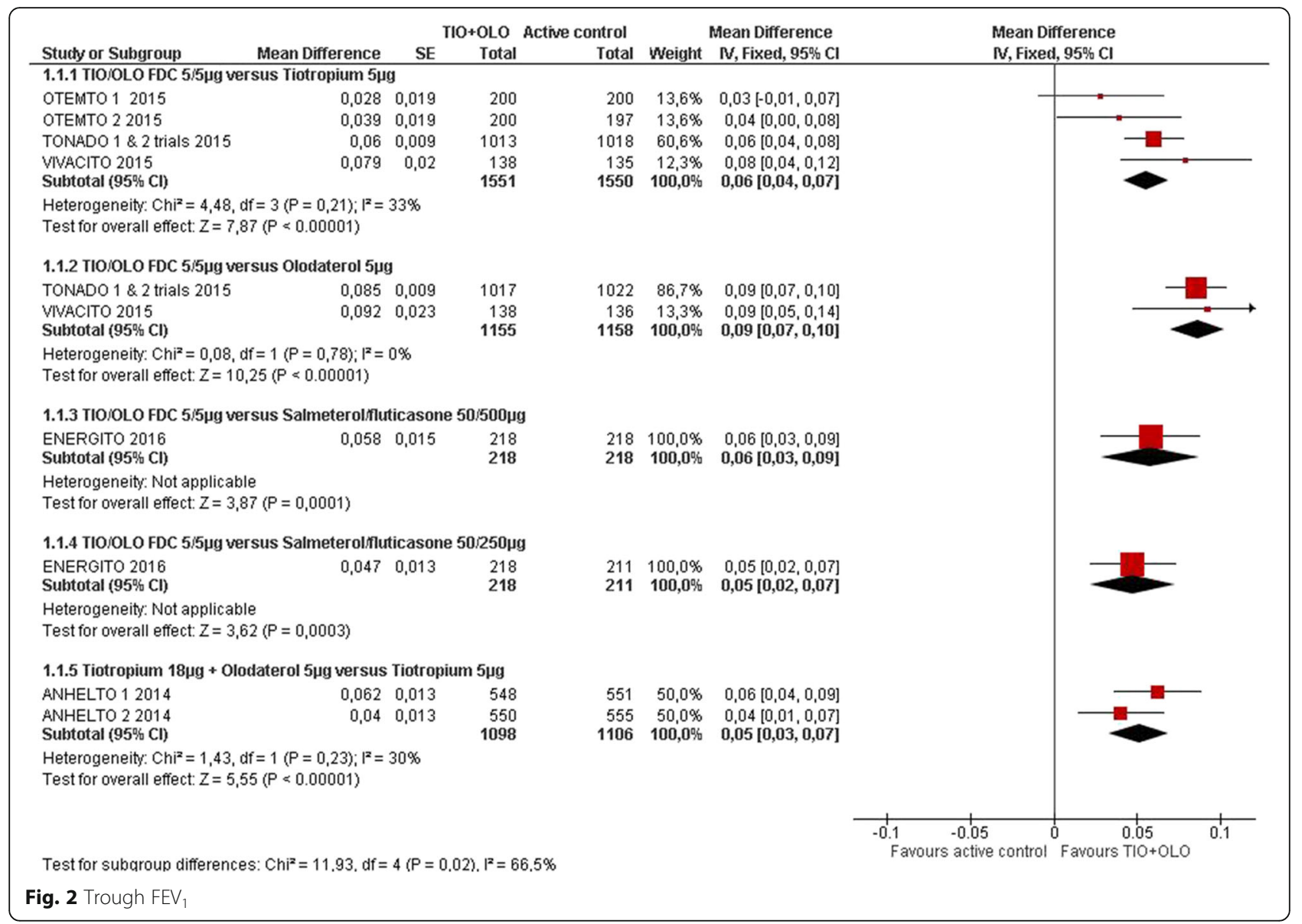

These results concur with those obtained with other LABA/LAMA FDC, that also demonstrate to provide better outcomes compared with mono-components [28$30]$ and with LABA/ICS [31, 32] and support the recent GOLD update that recommends LABA/LAMA as first line therapy in patients classified as GOLD D (more symptoms and increased risk of exacerbations) [1]. In a different approach based on clinical phenotypes, the Spanish guideline of management of COPD in its 2017 update recommends LABA/LAMA as first line therapy

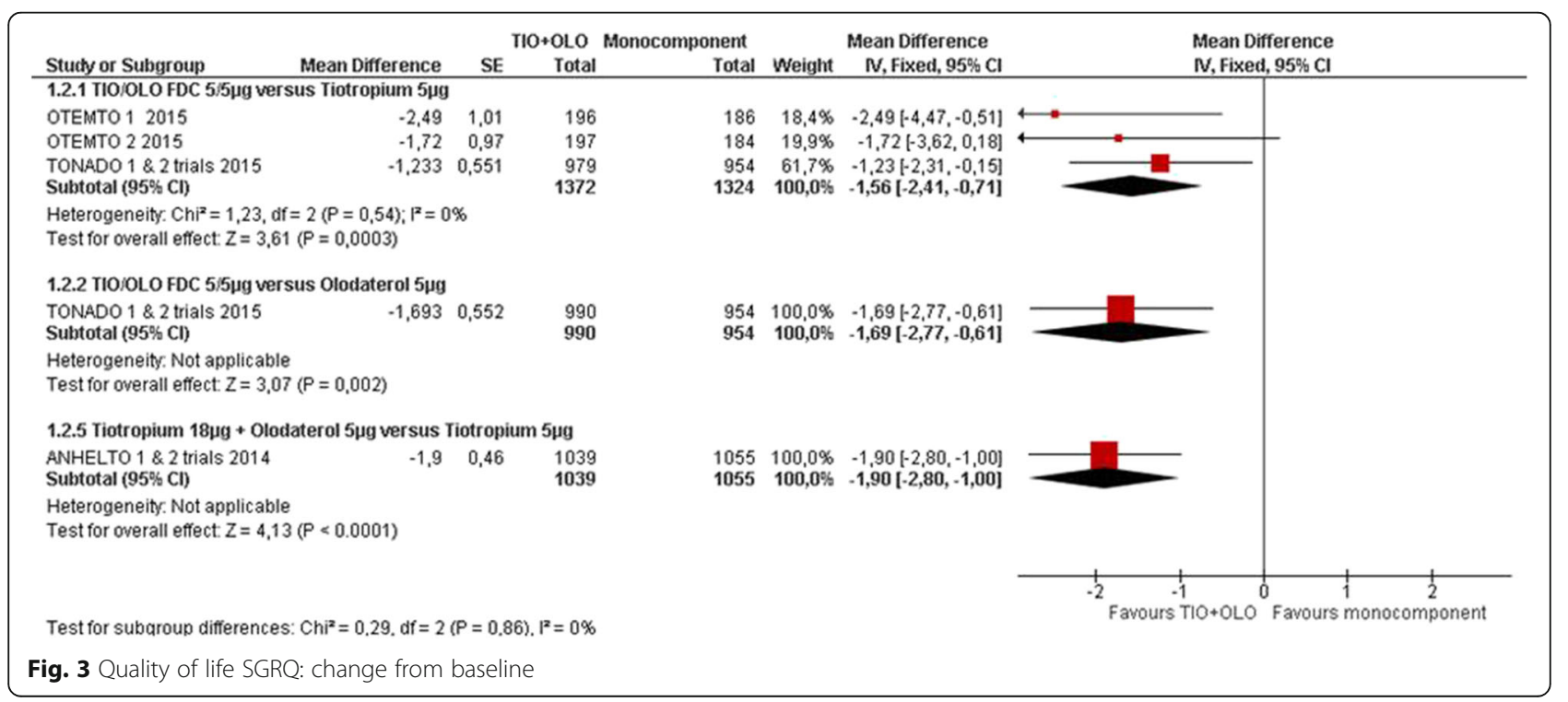




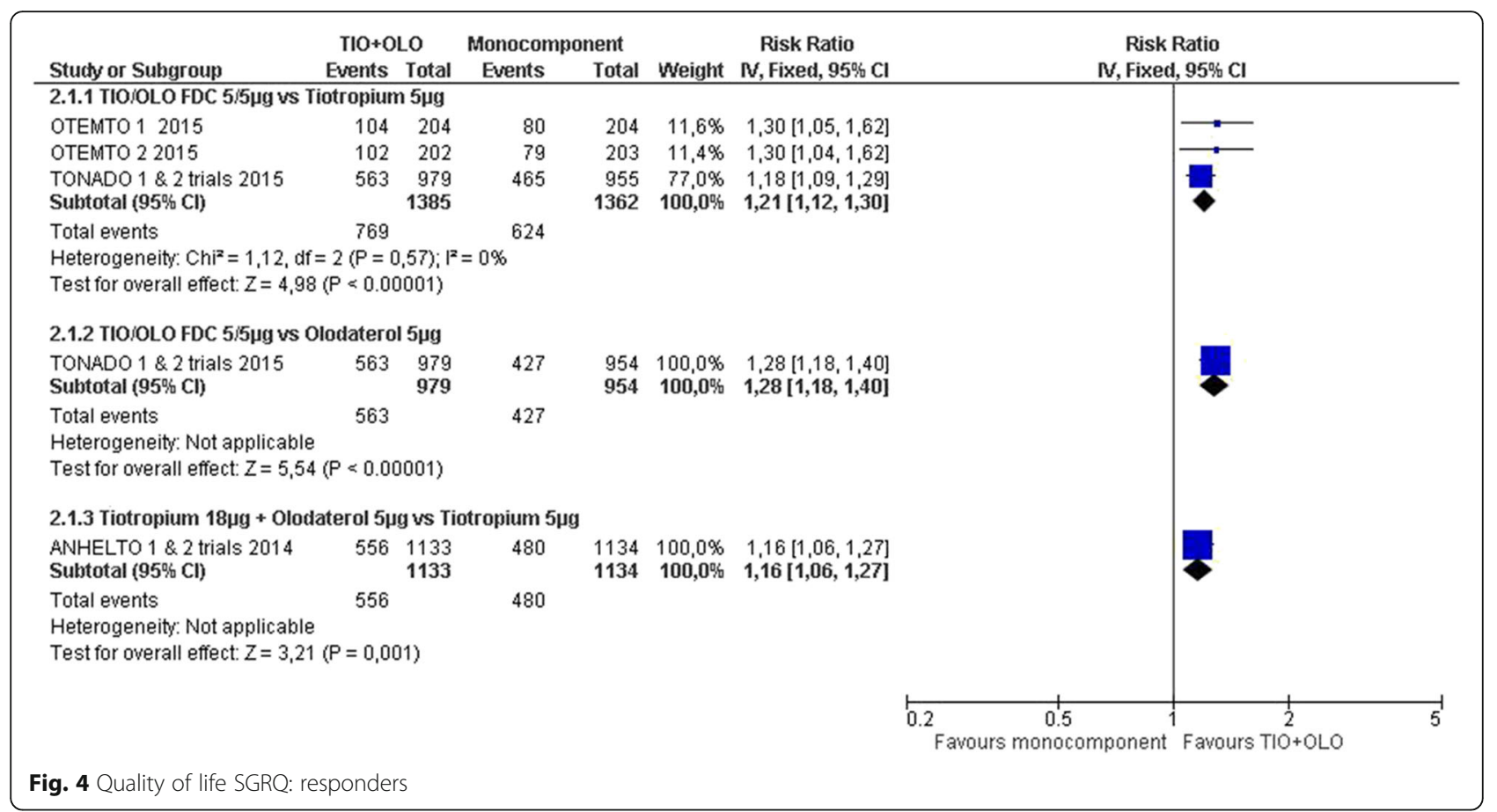

in patients classified as high risk (either $\mathrm{FEV}_{1}$ (\% predicted) $<50 \%$ or $\mathrm{MRC} \geq 2$ or $>1$ exacerbations or 1 hospitalization in the previous year) irrespective of the phenotype, with the exception of the asthma-COPD overlap (ACO) in which LABA/ICS is considered the preferred initial option [8].

The current analysis was based on 10 completed RCTs with TIO/OLO in COPD patients. Of these, only 2 RCTs used the combination of TIO and OLO administered with separate inhalers [14]. The remaining 8 RCTs used TIO/OLO FDC administered with the same inhaler (Respimat $\left.{ }^{\circ}\right)$. These studies evaluated adult patients ( $\geq 40$ years), predominantly men, smokers or ex-smokers, with moderate and severe COPD, even two of the trials included up to $10.8 \%$ of patients with very severe $\mathrm{COPD}\left(\mathrm{FEV}_{1}(\%)<30 \%\right)$. All trials were considered of high-quality, both in terms of design and execution, and the risk of bias in the estimation of the effect was perceived as low.

The combination of TIO/OLO demonstrated a mean improvement in trough $\mathrm{FEV}_{1}$ of between $60 \mathrm{~mL}$ to $90 \mathrm{~mL}$ over TIO and OLO, respectively. This improvement is in line of the mean improvement observed with dual bronchodilators versus LAMA alone [5]. Interestingly, the superiority of TIO/OLO in terms of lung function was observed consistently in all analyzed RCTs.

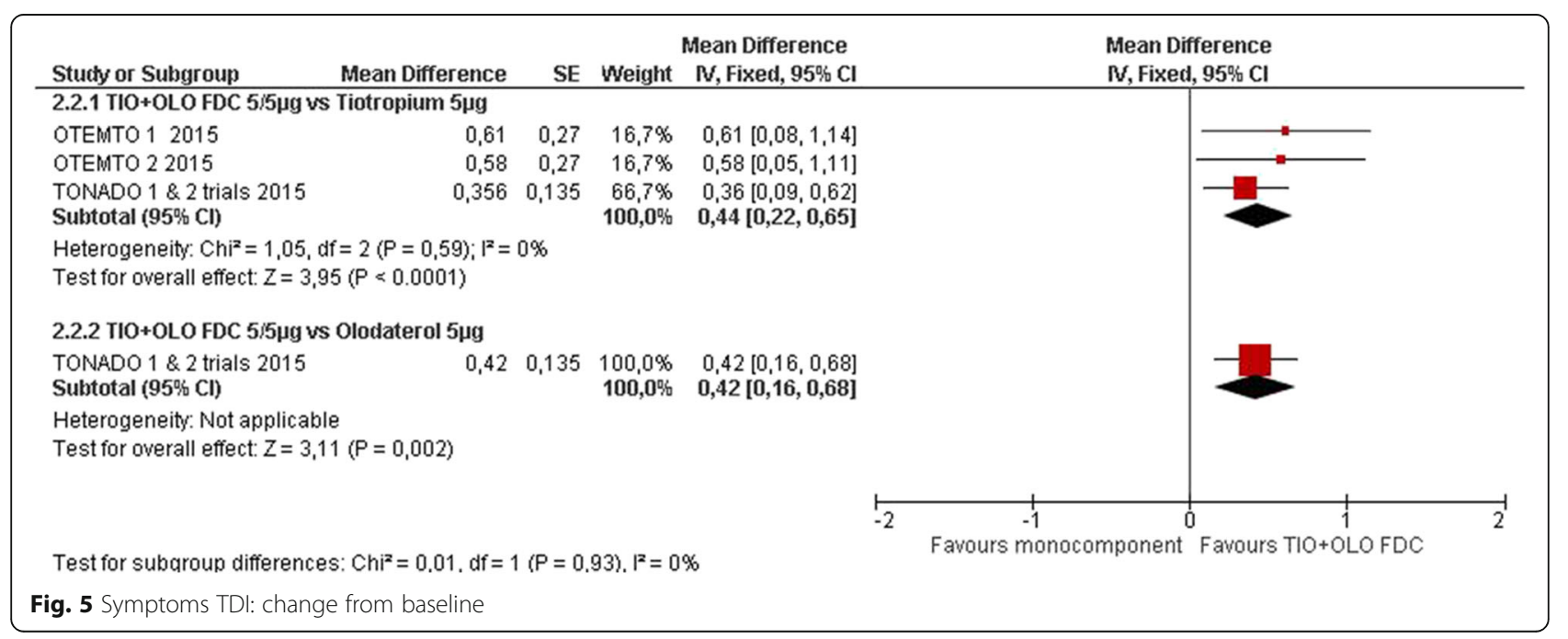




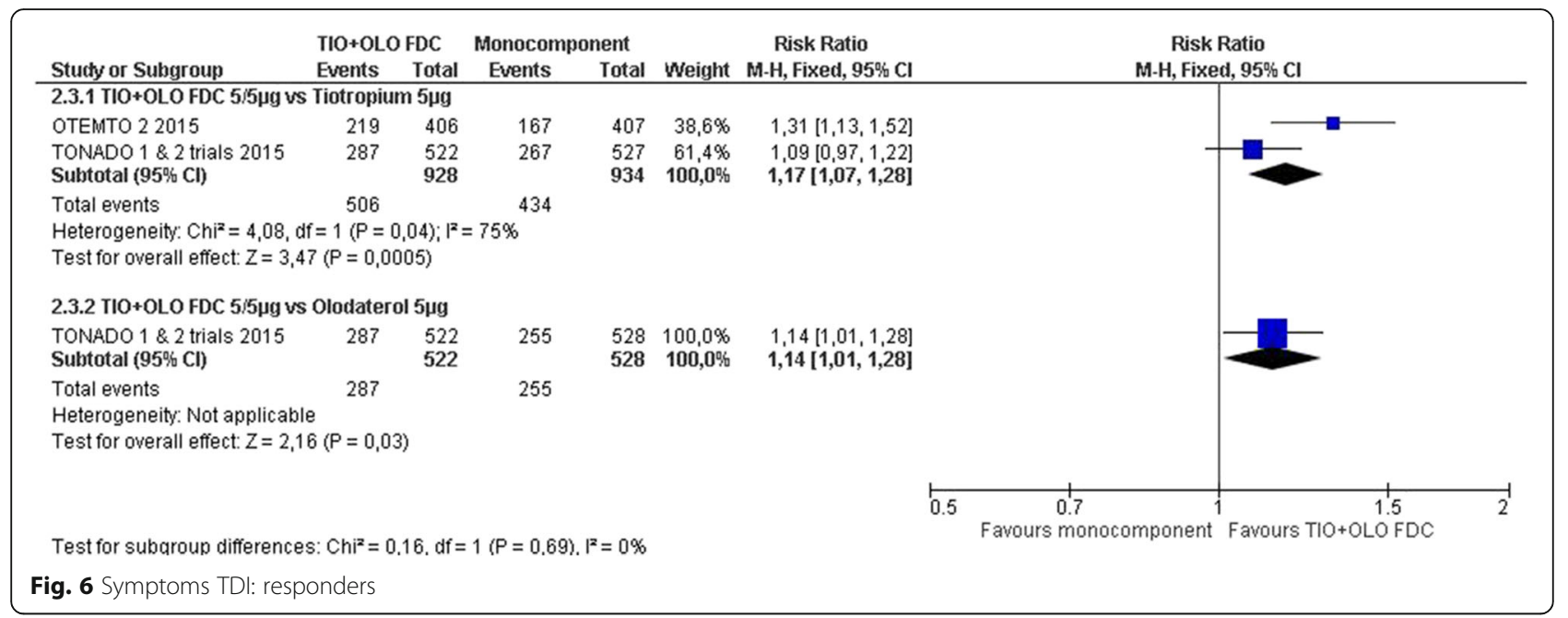

The results observed in lung function were paralleled with significant improvements in the SGRQ. The mean differences in scores did not reach the 4 units considered clinically relevant [33], but the probability of having a response superior to 4 units were significantly increased by $21 \%$ versus TIO and $28 \%$ versus OLO. Mean differences of around 4 units have only been observed between dual bronchodilation and placebo [33], but studies comparing LABA/LAMA combinations with mono-components have shown mean differences below that threshold, as observed in our analysis [28, 30]. However it is important to highlight the increased likelihood of achieving a clinically significant improvement in quality of life with TIO/OLO, which may be very relevant in more severe patients.
The current analysis has shown that TIO/OLO led to improved TDI compared to TIO and OLO alone. Patients on TIO/OLO had $17 \%$ higher probability to experience an improvement $>1$ unit in the TDI dyspnea score versus patients treated with $\mathrm{TIO}$ and $14 \%$ versus OLO. These results are also consistent with those reported for other LABA/LAMA FDC, where combinations improve significantly TDI scores over monotherapies, but mean differences do not achieve the 1 unit threshold $[28,30]$. However, all combinations increase the probability of a patient to reach a clinically significant improvement in dyspnea.

Rescue medication use and/or days free of rescue medication were assessed in six trials. TIO/OLO significantly reduced the use of rescue medication. This effect

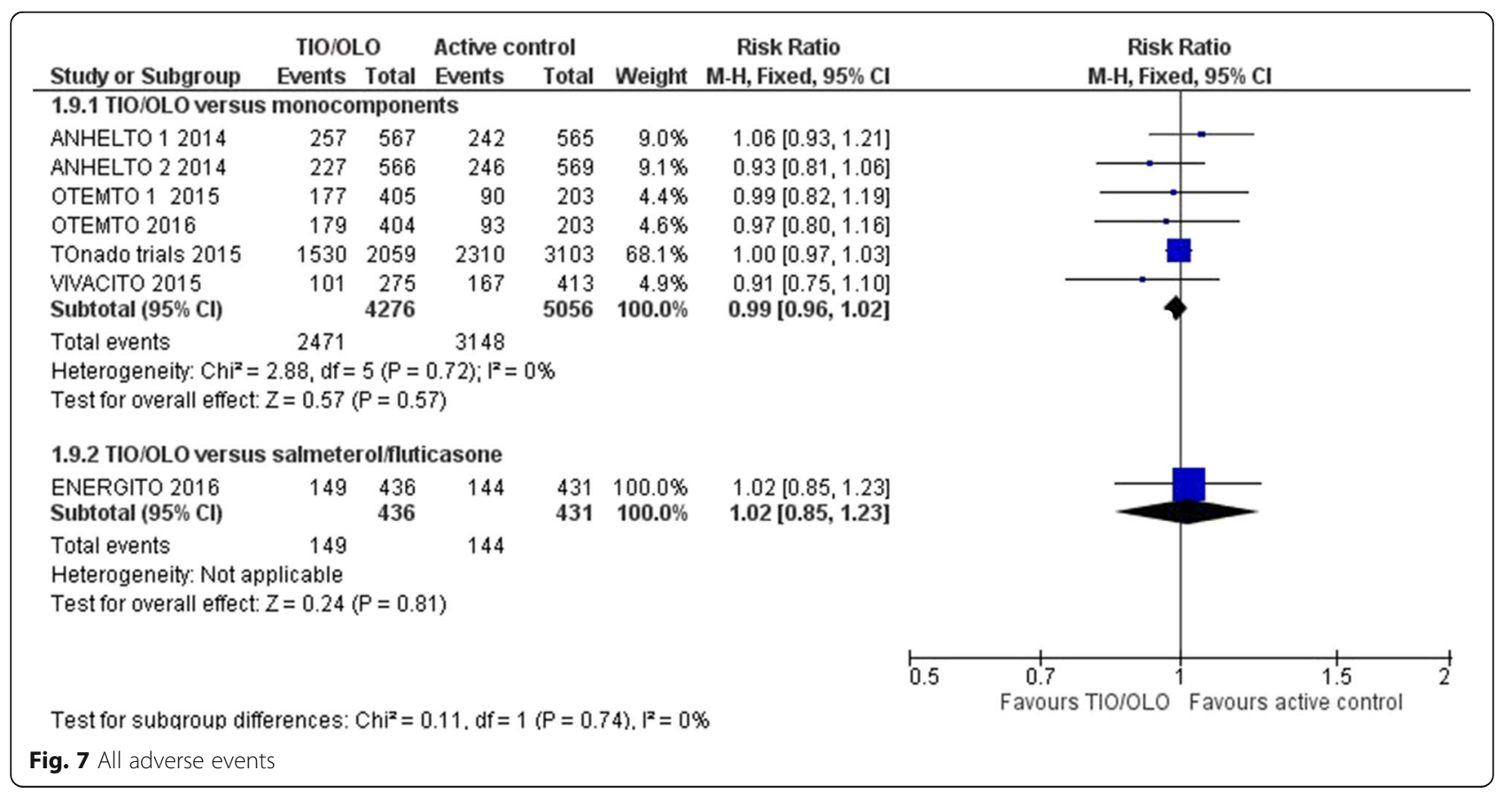


was observed throughout the 52-week follow-up in TONADO $1 \& 2$. The decrease in the use of rescue medication is one of the proposed markers for clinical control in COPD [34] and is associated with a decrease risk of exacerbations [35].

In two RCTs, TIO/OLO showed a non-significant trend towards an increase in exercise capacity compared to both monotherapies. These results are similar to those obtained with other LABA/LAMA FDC [36] and indicate that exercise limitation in COPD is multifactorial and significant improvements in lung function do not immediately translate into significant increases in exercise capacity. Other factors such as comorbidities and deconditioning may influence the reduced exercise capacity in COPD.

Regarding safety, no differences were observed in the frequency of general and serious adverse effects between TIO/OLO FDC and the mono-components; thus reassuring the excellent safety profile of this combination [37].

The strengths of the review are those typical of a systematic review: exhaustive search for studies, a reasonably high number of available studies, studies of high methodological quality, possibility of performing a metaanalysis, low heterogeneity and high consistency between studies. However, as limitations we highlight that all clinical trials were performed by the same pharmaceutical company, common limitation when a drug is reviewed by a meta-analysis. Another limitation is that it was not possible to do a subgroup analysis according to the patient's baseline level of severity and a different design related to variable duration of clinical trials (between 6 and 24 weeks).

\section{Conclusions}

$\mathrm{TIO} / \mathrm{OLO}$ is an effective and safe treatment for patients with COPD of any degree of severity. The improvements obtained in lung function are superior to those observed with monotherapies or with LABA/ICS combination. These improvements also translate with different intensity to improvements in other patient-reported outcomes.

\section{Additional files}

Additional file 1: Figure S3. Detailed search strategy. (DOCX $14 \mathrm{~kb}$ ) Additional file 2: Table S1. Characteristics of the included studies. (DOCX $121 \mathrm{~kb}$ )

Additional file 3: Figure S1. Risk of bias graph. (JPEG $40 \mathrm{~kb}$ )

Additional file 4: Figure S2. Risk of bias summary. (JPEG $60 \mathrm{~kb}$ )

\section{Acknowledgements}

Not applicable.

\section{Funding}

Systematic Review, Meta-Analysis and Medical writing assistance was supported financially by Boehringer Ingelheim. Boehringer Ingelheim was given the opportunity to check the data used in this manuscript for factual accuracy only.
Availability of data and materials

Data are available from the authors upon request.

\section{Authors' contributions}

All authors read and met ICMJE criteria for authorship. MM, GU had full access to all of the data in the study and take responsibility for the integrity of the data and the accuracy of the data analysis and wrote the manuscript. AGM and JA contributed substantially to the study design, data analysis and interpretation and the writing of the manuscript. All authors read and approved the final manuscript.

Ethics approval and consent to participate

Not applicable.

\section{Consent for publication}

Not applicable.

\section{Competing interests}

Marc Miravitlles has received speaker fees from Boehringer Ingelheim, AstraZeneca, Chiesi, GlaxoSmithKline, Menarini, Teva, Grifols and Novartis, and consulting fees from Boehringer Ingelheim, GlaxoSmithKline, Gebro Pharma, CLS Behring, Cipla, Medilmmune, Mereo Biopharma, Teva, Novartis and Grifols. Gerard Urrútia has received fees from GlaxoSmithKline and Novartis for participating in educational activities (workshops). Alexander G. Mathioudakis has not conflict of interest. Julio Ancochea has received speaker fees and/or consulting fees from Actelion, Air Liquide, Almirall, Astra-Zeneca, Boehringer-Ingelheim, Carburos Médica, Chiesi, Faes Farma, Ferrer, Glaxo-SmithKline, InterMune, Linde Healthcare, Menarini, MSD, Mundipharma, Novartis, Pfizer, Roche, Rovi, Sandoz, Takeda and Teva.

\section{Publisher's Note}

Springer Nature remains neutral with regard to jurisdictional claims in published maps and institutional affiliations.

\section{Author details}

'Pneumology Department, Hospital Universitari Vall d'Hebron., P. Vall d'Hebron 119-129, ES-08035 Barcelona, Spain. ${ }^{2}$ Institut d'Investigació Biomèdica Sant Pau (IIB Sant Pau). CIBER de Epidemiología y Salud Pública (CIBERESP), Barcelona, Spain. ${ }^{3}$ Division of Infection, Immunity and Respiratory Medicine, University Hospital of South Manchester, The University of Manchester, Manchester, UK. ${ }^{4}$ Pneumology Department, Hospital Universitario de La Princesa, Instituto de Investigación Hospital Universitario de la Princesa (IISP) Universidad Autónoma de Madrid, Madrid, Spain.

Received: 20 September 2017 Accepted: 15 November 2017 Published online: 25 November 2017

\section{References}

1. Vogelmeier CF, Criner GJ, Martínez FJ, Anzueto A, Barnes PJ, Bourbeau J et al. Global strategy for the diagnosis, management, and prevention of chronic obstructive lung disease 2017 report: GOLD executive summary. Arch Bronconeumol. 2017:53:128-49.

2. Kew KM, Dias S, Cates CJ. Long-acting inhaled therapy (beta-agonists, anticholinergics and steroids) for COPD: a network meta-analysis. Cochrane Database Syst Rev. 2014;3:CD010844.

3. Tashkin DP, Celli B, Senn S, Burkhart D, Kesten S, Menjoge S, et al. A 4-year trial of tiotropium in chronic obstructive pulmonary disease. N Engl J Med. 2008;359(15):1543-54.

4. Mathioudakis AG, Kanavidis P, Chatzimavridou-Grigoriadou V, Gialmanidis IP, Amanetopoulou SG, Christopoulou E, et al. Tiotropium HandiHaler improves the survival of patients with COPD: a systematic review and meta-analysis. J Aerosol Med Pulm Drug Deliv. 2014;27(1):43-50.

5. Schlueter M, Gonzalez-Rojas N, Baldwin M, Groenke L, Voss F, Reason T. Comparative efficacy of fixed-dose combinations of long-acting muscarinic antagonists and long-acting $\beta 2$-agonists: a systematic review and network meta-analysis. Ther Adv Respir Dis. 2016;10(2):89-104.

6. Rodrigo GJ, Price D, Anzueto A, Singh D, Altman P, Bader G, et al. LABA/LAMA combinations versus LAMA monotherapy or LABA/ICS in COPD: a systematic review and meta-analysis. Int J Chron Obstruct Pulmon Dis. 2017;12:907-22.

7. Horita N, Goto A, Shibata Y, Ota E, Nakashima K, Nagai K, et al. Long-acting muscarinic antagonist (LAMA) plus long-acting beta-agonist (LABA) versus 
LABA plus inhaled corticosteroid (ICS) for stable chronic obstructive pulmonary disease (COPD). Cochrane Database of Systematic Reviews 2017, Issue 2. Art. No:: CD012066. DOI: https://doi.org/10.1002/14651858. CD012066.pub2.

8. Miravitlles M, Soler-Cataluña JJ, Calle M, Molina J, Almagro P, Quintano JA, et al. Spanish COPD guidelines (GesEPOC) 2017. Pharmacological treatment of stable chronic obstructive pulmonary disease. Arch Bronconeumol. 2017; 53:324-35.

9. Ferguson GT, Feldman GJ, Hofbauer P, Hamilton A, Allen L, Korducki L, et al. Efficacy and safety of olodaterol once daily delivered via Respimat ${ }^{\ominus}$ in patients with GOLD 2-4 COPD: results from two replicate 48-week studies. Int J Chron Obstruct Pulmon Dis. 2014;9:629-45.

10. Calzetta L, Ciaprini C, Puxeddu E, Cazzola M. Olodaterol + tiotropium bromide for the treatment of COPD. Expert Rev Respir Med. 2016:1-8.

11. Derom E, Brusselle GG, Joos GF. Efficacy of tiotropium-olodaterol fixed-dose combination in COPD. Int J Chron Obstruct Pulmon Dis. 2016;11:3163-77.

12. Moher D, Liberati A, Tetzlaff J, Altman DG, Group P. Preferred reporting items for systematic reviews and meta-analyses: the PRISMA statement. BMJ. 2009;339:b2535.

13. Higgins JPT, Green S (editors). Cochrane Handbook for Systematic Reviews of Interventions Version 5.1.0 [updated March 2011]. The Cochrane Collaboration, 2011. Available from www.handbook.cochrane.org.

14. ZuWallack R, Allen L, Hernandez G, Ting N, Abrahams R. Efficacy and safety of combining olodaterol Respimat ${ }^{\oplus}$ and tiotropium HandiHaler ${ }^{\oplus}$ in patients with COPD: results of two randomized, double-blind, active-controlled studies. Int J Chron Obstruct Pulmon Dis. 2014;9:1133-44.

15. Beeh KM, Derom E, Echave-Sustaeta J, Grönke L, Hamilton A, Zhai D, et al. The lung function profile of once-daily tiotropium and olodaterol via Respimat ${ }^{\oplus}$ is superior to that of twice-daily salmeterol and fluticasone propionate via Accuhaler ${ }^{\circledR}$ (ENERGITO ${ }^{\oplus}$ study). Int J Chron Obstruct Pulmon Dis. 2016;11:193-205.

16. Effect on Exercise Endurance and Lung Hyperinflation of Tiotropium + Olodaterol in COPD Patients. [Accessed December 12, 2014]. ClinicalTrials. gov Identifier: NCT01533922; 2012 [updated April 30, 2014]. Available from: https://clinicaltrials.gov/ct2/show/NCT01533922.

17. Effect on Exercise Endurance and Lung Hyperinflation of Tiotropium + Olodaterol in COPD Patients. [Accessed December 12, 2014]. ClinicalTrials. gov Identifier: NCT01533935; 2012 [updated April 30, 2014]. Available from: https://clinicaltrials.gov/ct2/show/NCT01533935.

18. Singh D, Ferguson GT, Bolitschek J, Grönke L, Hallmann C, Bennett N, et al. Tiotropium + olodaterol shows clinically meaningful improvements in quality of life. Respir Med. 2015;109(10):1312-9.

19. Singh D, Gaga M, Schmidt O, Bjermer L, Grönke L, Voß F, et al. Effects of tiotropium+olodaterol versus tiotropium or placebo by COPD disease severity and previous treatment history in the OTEMTO ${ }^{\circ}$ studies. Respir Res. 2016;17(1):73.

20. Buhl R, Maltais F, Abrahams R, Bjermer L, Derom E, Ferguson G, et al. Tiotropium and olodaterol fixed-dose combination versus monocomponents in COPD (GOLD 2-4). Eur Respir J. 2015:45(4):969-79.

21. Ferguson GT, Fležar M, Korn S, Korducki L, Grönke L, Abrahams R, et al. Efficacy of Tiotropium + Olodaterol in patients with chronic obstructive pulmonary disease by initial disease severity and treatment intensity: a post hoc analysis. Adv Ther. 2015:32(6):523-36.

22. Beeh KM, Westerman J, Kirsten AM, Hébert J, Grönke L, Hamilton A, et al. The 24-h lung-function profile of once-daily tiotropium and olodaterol fixed-dose combination in chronic obstructive pulmonary disease. Pulm Pharmacol Ther. 2015;32:53-9.

23. Bourbeau J, Lavoie KL, Sedeno M, De Sousa D, Erzen D, Hamilton A, et al. Behaviour-change intervention in a multicentre, randomised, placebocontrolled COPD study: methodological considerations and implementation. BMJ Open. 2016;6(4):e010109.

24. Troosters T, Bourbeau J, Maltais F, Leidy N, Erzen D, De Sousa D, et al. Enhancing exercise tolerance and physical activity in COPD with combined pharmacological and non-pharmacological interventions: PHYSACTO randomised, placebocontrolled study design. BMJ Open. 2016;6(4):e010106.

25. Comparing the Efficacy of Tiotropium + Olodaterol $(5 / 5 \mu \mathrm{g})$ Fixed Dose Combination (FDC) Over Tiotropium $5 \mu \mathrm{g}$ in Reducing Moderate to Severe Exacerbations in Patients With Severe to Very Severe Chronic Obstructive Pulmonary Disease. [Accessed December 12, 2014]. ClinicalTrials.gov Identifier: NCT02296138; 2014 [updated December 11, 2014]. Available from: http://clinicaltrials.gov/ct2/show/NCT02296138.
26. Aalbers R, Maleki-Yazdi MR, Hamilton A, Waitere-Wijker S, Zhao Y, Amatto VC, et al. Randomized, double-blind, dose-finding study for Tiotropium when added to Olodaterol, administered via the Respimat ${ }^{\oplus}$ inhaler in patients with chronic obstructive pulmonary disease. Adv Ther. 2015;32(9): 809-22.

27. Maltais F, Gáldiz Iturri JB, Kirsten A, Singh D, Hamilton A, Tetzlaff $K$, et al. (P250) effects of 12 weeks of once-daily tiotropium and olodaterol fixeddose combination on exercise endurance in patients with COPD. Thorax. 2014;69(suppl 2):A186-7. https://doi.org/10.1136/thoraxjnl-2014-206260.378.

28. Bateman ED, Ferguson GT, Barnes N, Gallagher N, Green Y, Henley M, et al. Dual bronchodilation with QVA149 versus single bronchodilator therapy: the SHINE study. Eur Respir J. 2013;42(6):1484-94.

29. Decramer M, Anzueto A, Kerwin E, Kaelin T, Richard N, Crater G, et al. Efficacy and safety of umeclidinium plus vilanterol versus tiotropium, vilanterol, or umeclidinium monotherapies over 24 weeks in patients with chronic obstructive pulmonary disease: results from two multicentre, blinded, randomised controlled trials. Lancet Respir Med. 2014;2(6):472-86.

30. Singh D, Worsley S, Zhu CQ, Hardaker L, Church A. Umeclidinium/vilanterol versus fluticasone propionate/salmeterol in COPD: a randomised trial. BMC Pulm Med. 2015;15:91.

31. Vogelmeier C, Paggiaro PL, Dorca J, Sliwinski $\mathrm{P}$, Mallet M, Kirsten AM, et al. Efficacy and safety of aclidinium/formoterol versus salmeterol/fluticasone: a phase 3 COPD study. Eur Respir J. 2016;48(4):1030-9.

32. Vogelmeier CF, Bateman ED, Pallante J, Alagappan VK, D'Andrea P, Chen H, et al. Efficacy and safety of once-daily QVA149 compared with twice-daily salmeterol-fluticasone in patients with chronic obstructive pulmonary disease (ILLUMINATE): a randomised, double-blind, parallel group study. Lancet Respir Med. 2013;1(1):51-60.

33. Siler TM, Donald AC, O'Dell D, Church A, Fahy WAA. Randomized, parallelgroup study to evaluate the efficacy of umeclidinium/vilanterol 62.5/25 $\mu \mathrm{g}$ on health-related quality of life in patients with COPD. Int J Chron Obstruct Pulmon Dis. 2016;11:971-9.

34. Nibber A, Chisholm A, Soler-Cataluña JJ, Alcazar B, Price D, Miravitlles M. On behalf of the respiratory effectiveness group. Validating the concept of COPD control: a real-world cohort study from the United Kingdom. COPD. 2017;14:504-12.

35. Jenkins CR, Postma DS, Anzueto AR, Make BJ, Peterson S, Eriksson G, et al. Reliever salbutamol use as a measure of exacerbation risk in chronic obstructive pulmonary disease. BMC Pulm Med. 2015;15:97.

36. Maltais F, Singh S, Donald AC, Crater G, Church A, Goh AH, et al. Effects of a combination of umeclidinium/vilanterol on exercise endurance in patients with chronic obstructive pulmonary disease: two randomized, double-blind clinical trials. Ther Adv Respir Dis. 2014;8(6):169-81.

37. Buhl R, Magder S, Bothner U, Tetzlaff K, Voß F, Loaiza L, et al. Long-term general and cardiovascular safety of tiotropium/olodaterol in patients with moderate to very severe chronic obstructive pulmonary disease. Respir Med. 2017;122:58-66.

\section{Submit your next manuscript to BioMed Central and we will help you at every step:}

- We accept pre-submission inquiries

- Our selector tool helps you to find the most relevant journal

- We provide round the clock customer support

- Convenient online submission

- Thorough peer review

- Inclusion in PubMed and all major indexing services

- Maximum visibility for your research

Submit your manuscript at www.biomedcentral.com/submit
) Biomed Central 